
\title{
R Research S Suare \\ First Report of Cyamus Boopis from A Humpback Whale (Megaptera novaeangliae) in the Coastal East China Sea
}

\section{Ying Qiao}

Fourth Institute of Oceanogrophy

Xiaowan Ma ( $\nabla$ bowl_88@hotmail.com )

Bingyao Chen

Nanjing normal university

Shengping Zhong

GuangXi University of Chinese Medicine

\section{Xuyang Chen}

fourth institute of oceanography

Short report

Keywords: Megaptera novaeangliae, Cyamus boopis, Cyamidae, whale lice, East China Sea

Posted Date: July 21st, 2020

DOl: https://doi.org/10.21203/rs.3.rs-44880/v1

License: (c) (1) This work is licensed under a Creative Commons Attribution 4.0 International License.

Read Full License 


\section{Abstract}

Background: Cyamus boopis is an amphipod crustacean that obligately parasitizes the body surface of the humpback whale, Megaptera novaeangliae. The life cycle of $C$. boopis does not include a swimming stage, and the crustacean spends its entire life on the body of $M$. novaeangliae.

Methods: On November 15, 2017, a male humpback whale was found stranded on the coast of the cape of Yuan Tuo, Qidong, Nantong, JiangSu province, China. Parasites were collected from the carcass of this whale and identified by morphological techniques and molecular analysis.

Results: A total of 15 C. boopis specimens were collected, and eight females and seven males were morphologically identified. A phylogenetic tree of cytochrome $\mathrm{c}$ oxidase subunit 1 revealed that the collected specimens clustered together with previously reported $C$. boopis sequences from the Northern Hemisphere.

Conclusion: This is the first report of $C$. boopis in a humpback whale from the East China Sea and supplements data from humpback whales found off the coast of China. In addition, our data provide supplementary data on the migration paths of humpback whales.

\section{Background}

Amphipod crustaceans, or whale lice, are common ectoparasites found in cetaceans. However, whale lice remain among the least understood crustaceans, despite their specialized biological features. To date, 28 species of Cyamidae from eight genera, including at least 15 species of Cyamus, Isocyamus, Neocyamus, Platycyamus and Syncyamus, have been reported all over the world [1]. Some cyamid species parasitize several species of cetaceans. However, Cyamus boopis is found only on humpback whales (Megaptera novaeangliae) [2-6].

Acute ventral processes formulas and maxilliped palp characters are usually used to identify cyamids [2, 7-10]. However, a lack of available descriptions and variations in morphological characteristics have led to the incorrect identification of some Cyamus juveniles [2, 7]. In particular, identification of $C$. boopis over the decades has been controversial. $C$. boopis was first described by Lütken, who collected specimens from M. novaeangliae in 1870 [11]. In the following few years, $C$. boopis was transferred to the new genus Paracyamus based on the uni-articulate maxilliped palp present in adults [12]. Later $C$. boopis was returned to the Cyamus genus [2]. At the genus level, $C$. boopis and Cyamus catodontis are similar, as both lack ventral processes on pereonites 3 and 4 and have a smooth grinding surface on the right lacinia mobilis $[7,10]$. This has led previous authors to confuse these two species. Therefore, in addition to morphological identification, molecular methods are required for proper identification.

The life cycle of whale lice does not include a swimming stage, and the parasite spends its entire life on the body of its whale host $[4,13]$. Therefore, whale lice are a potential tool for studying humpback whale migratory routes around the world $[6,14]$. Although there have been persistent reports of whale lice in the 
Northern Hemisphere, molecular data on these parasites are still relatively scant $[5,14,15]$. M. novaeangliae are one of the most cosmopolitan whales in the world [16]. The migration patterns of humpback whales have been extensively studied over the last few decades. However, there is still a gap in data on M. novaeangliae in the Northern Hemisphere, especially near China.

In this study, we describe the first known case of whale lice collected from a humpback whale stranded on the coast of the East China Sea. Based on morphological identification and cytochrome c oxidase subunit 1 (COI) gene sequence analysis, we confirmed that the lice belonged to $C$. boopis. This report supplements data on $C$. boopis and its humpback whale hosts off the coast of China and provides information on the possible migration paths of humpback whales.

\section{Methods}

Whale lice (JS isolate) were collected from the carcass of a male humpback whale (body length, $6.62 \mathrm{~m}$ ) on the coast of the East China Sea on the cape of Yuan Tuo, Qidong, Nantong, Jiangsu province, China (N $31^{\circ} 44^{\prime} 28^{\prime \prime}$, E $\left.121^{\circ} 56^{\prime} 10^{\prime \prime}\right)$ on November 15, 2017 (Graphical Abstract).

Parasites were fixed and preserved in 70\% ethanol. Microscopic examinations were performed using an Olympus BX53 (Olympus, Tokyo, Japan) with an adapted Canon EOS R camera (Canon, Tokyo, Japan). Morphological characteristics and descriptions were used to identify parasites according to previous reports $[2,7,10]$. Drawings were digitally prepared using Adobe Illustrator CS6 (Adobe Inc., San Jose, CA, USA).

Genomic DNA was extracted from the pereopod of each specimen using a QIAamp Fast DNA Tissue Kit (Cat No.51404, QIAGEN, Hilden, Germany) following the manufacturer's instructions. DNA samples were stored at $-20^{\circ} \mathrm{C}$ until polymerase chain reaction (PCR) amplifications were performed. The COI gene was amplified using the following primers: C01F, 5'-TGGCATCGTTTCTCACGTAG-3'; and C01R, 5'GGGTGATACCATTCTACAGCG-3'. Primer synthesis and PCR product sequencing were performed by Sangon Biotech (Shanghai, China).

To examine phylogenetic relationships, homologous sequences were selected and multiple alignments were performed using ClustalX2. A maximum likelihood tree was constructed using the online program PhyML 3.0 (http://www.atgc-montpellier.fr/phyml/) with Smart Model Selection [17]. The Akaike Information Criterion model was selected with Subtree Pruning and Regrafting as the type of tree improvement. The number of bootstrap replicates was 100 . All sequences included in the phylogenetic tree were retrieved from the GenBank database (Table 1). 
Table 1

Sequence information included in the phylogenetic tree

\begin{tabular}{|c|c|c|c|c|}
\hline No. & Accsession No. & Ocean & Hemisphere & Reference \\
\hline & \multicolumn{4}{|l|}{ Cyamus boopis } \\
\hline 1 & MT458501 & WNP & $\mathrm{NH}$ & present study \\
\hline 2 & DQ095150.1 & NP & $\mathrm{NH}$ & Kaliszewska,Z.A. et al, 2005 \\
\hline 3 & FJ751159.1 & NP & $\mathrm{NH}$ & \multirow[t]{2}{*}{ Callahan,C.M. et al,2008 } \\
\hline 4 & FJ751158.1 & NP & $\mathrm{NH}$ & \\
\hline 5 & MG720511.1 & WSP & $\mathrm{SH}$ & \multirow[t]{11}{*}{ Iwasa-Arai,T. et al,2018 } \\
\hline 6 & MG720513.1 & WSP & $\mathrm{SH}$ & \\
\hline 7 & MG720500.1 & ESA & $\mathrm{SH}$ & \\
\hline 8 & MG720497.1 & WSA & $\mathrm{SH}$ & \\
\hline 9 & MG720490.1 & WSA & $\mathrm{SH}$ & \\
\hline 10 & MG720494.1 & WSA & $\mathrm{SH}$ & \\
\hline 11 & MG720519.1 & WSA & $\mathrm{SH}$ & \\
\hline 12 & MG720533.1 & WSA & $\mathrm{SH}$ & \\
\hline 13 & MG720523.1 & WSA & $\mathrm{SH}$ & \\
\hline 14 & MG720528.1 & WSA & $\mathrm{SH}$ & \\
\hline \multirow[t]{2}{*}{15} & MG720479.1 & WSA & $\mathrm{SH}$ & \\
\hline & \multicolumn{4}{|l|}{ Cyamus erraticus } \\
\hline 16 & DQ095128.1 & NP & $\mathrm{NH}$ & \multirow[t]{6}{*}{ Kaliszewska,Z.A. et al, 2005} \\
\hline 17 & DQ095129.1 & SO & $\mathrm{SH}$ & \\
\hline 18 & DQ095139.1 & SO & $\mathrm{SH}$ & \\
\hline 19 & DQ095134.1 & so & $\mathrm{SH}$ & \\
\hline 20 & DQ095135.1 & so & $\mathrm{SH}$ & \\
\hline 21 & DQ095107.1 & NA & $\mathrm{NH}$ & \\
\hline 22 & DQ095127.1 & NA & $\mathrm{NH}$ & - \\
\hline 23 & DQ095106.1 & NA & $\mathrm{NH}$ & - \\
\hline $\begin{array}{l}\text { WNF } \\
\text { Atla } \\
\text { Sout }\end{array}$ & stern north pacifi & North $P_{c}$ & $\begin{array}{l}\text {; WSP: Weste } \\
\text { orth Pacific; }\end{array}$ & $\begin{array}{l}\text { uth Pacific; ESA: Eastern South } \\
\text { uthern ocean; NA: North atlantic; SH: }\end{array}$ \\
\hline
\end{tabular}




\begin{tabular}{|c|c|c|c|c|}
\hline No. & Accsession No. & Ocean & Hemisphere & Reference \\
\hline & \multicolumn{4}{|l|}{ Cyamus gracilis } \\
\hline 24 & DQ095104.1 & - & - & - \\
\hline 25 & DQ095096.1 & - & - & - \\
\hline 26 & DQ095087.1 & so & $\mathrm{SH}$ & - \\
\hline 27 & DQ095100.1 & - & - & - \\
\hline 28 & DQ095092.1 & - & - & - \\
\hline 29 & DQ095048.1 & NA & $\mathrm{NH}$ & - \\
\hline 30 & DQ095089.1 & so & $\mathrm{SH}$ & - \\
\hline 31 & DQ095102.1 & so & $\mathrm{SH}$ & - \\
\hline 32 & DQ095050.1 & NA & $\mathrm{NH}$ & - \\
\hline 33 & DQ095049.1 & NA & $\mathrm{NH}$ & - \\
\hline
\end{tabular}

\section{Results}

All whale lice exhibited specific features that allowed for sex and species identification. In total, eight female and seven male $C$. boopis specimens were identified. $C$. boopis adults differ from other Cyamus species by the number of ventral processes on pereonites $5-7$. Sex was assigned based on several characteristics: pereonites 3 and 4 are broader than those of males; subequal in width to pereonites 5 and 6; and the pleons of females lack pleopods (Fig. 1).

The phylogenetic tree showed that the sequence of the collected specimens (JS isolate) clustered with all other reported $C$. boopis $\mathrm{COI}$ sequences but was separate from other Cyamus species (Fig. 2). The sequence was deposited in the GenBank database (accession number, MT551876).

\section{Discussion}

To the best of our knowledge, this is the first report of $C$. boopis in a humpback whale in Chinese waters In general, research on humpback whales and whale lice in China is rare. There has been only one report of a North Atlantic right whale, Eubalaena glacialis, stranded on the coast of the Yellow Sea in China (N $38^{\circ} 55^{\prime}, \mathrm{E} 123^{\circ} 40^{\prime}$ ) in 1977 on which three species of whale lice (Cyamus erraticus, Cyamus scammoni and Cyamus ovalis) were identified [18]. Our report extends findings of humpback whales and whale lice in China. 
Using morphological identification, the specimens collected from the humpback whale stranded on the coast of the East China were found to belong to $C$. boopis. Combined with mitochondrial DNA analysis of the $\mathrm{COI}$ sequence, we found that the $C$. boopis specimens clustered together with all other specimens from the Northern Hemisphere. A previous study compared C. boopis from three M. novaeangliae breeding stocks from the Southern Hemisphere with $C$. boopis from the Northern Hemisphere using the $\mathrm{COI}$ gene sequences and found that $C$. boopis from the two locations differed greatly in genetic structure [6]. However, data from the Northern Hemisphere was based on only three samples of $C$. boopis. Therefore, data on $C$. boopis and humpback whales in the Northern Hemisphere are lacking compared with those from the Southern Hemisphere.

Some studies have suggested that, in addition to $C$. boopis, $C$. elongatus may also parasitize humpback whales [13]. However, molecular studies of Brazilian $C$. boopis confirmed that all specimens of whale lice collected from $M$. novaeangliae were from the same species [2, 7]. Our study confirmed that the specimen collected from the humpback whale in China was also $C$. boopis. Therefore, more data are needed to support the presence of $C$. elongatus on humpback whales.

Whale lice can provide valuable information about whale population histories. Because whale lice have no alternative hosts or free-living stages and have a long history of living on their whale hosts $[4,19]$. In addition, because of their short generation time [19] and large population size [20], synonymous sequence divergence of homologous markers of Cyamidae can be ten times faster than that of their whale hosts [14]. The genetic structure of cyamids could also reveal encounters between whales of different stocks $[6,13]$. Although records have been collected of whale lice from Cetacea in coastal waters all over the world, molecular information on whale lice is still limited. Therefore, the collection of whale louse samples and their genetic data could provide a scientific basis for the classification and identification of whale lice and provide information for the further study of whale populations and migration.

\section{Conclusions}

To the best of our knowledge, this is the first report of $C$. boopis in humpback whale from China. This study extends the track of humpback whale over the world. The record of $C$. boopis provides important supplementary details and data for of studying the migration paths of humpback whales and population communication.

\section{Declarations}

\section{Ethics approval and consent to participate}

Not applicable.

\section{Consent for publication}


Not applicable.

\section{Availability of data and materials}

All data generated or analyzed during this study are included in this published article.

\section{Competing interests}

The authors declare that they have no competing interests.

\section{Funding}

This work was supported by Innovation Driven Development Foundation of Guangxi, Grant Number AD19245135 and AD19245161; and Major project of hydrobios resources in Jiangsu province邓the Priority Academic Programme Development of Jiangsu Higher Education Institutions (PAPD)

\section{Authors' contributions}

$Y Q$ wrote and designed the manuscript; XWM and XYC performed the morphology description and draw the figures; BYC collected and contributed the sample of the parasite; SPZ performed the molecular identification of the parasite; All authors read and approved the final manuscript.

\section{Acknowledgements}

Not applicable.

\section{Authors' information}

${ }^{1}$ Beibu Gulf Cetacean Research and Protection Center, Fourth Institute of Oceanography, Ministry of Natural Resources, Beihai 536000, China

2 Jiangsu Key Laboratory for Biodiversity and Biotechnology, College of Life Sciences, Nanjing Normal University, Nanjing 210023, China

${ }^{3}$ Institute of marine drugs, Guangxi University of Chinese Medicine, Nanning, 530200, China

\section{References}

1. Iwasaarai T, Serejo CS. Phylogenetic analysis of the family Cyamidae (Crustacea: Amphipoda): a review based on morphological characters. Zoological Journal of the Linnean Society. 2018;(184): 66-94.

2. Margolis L. Notes on the Morphology, Taxonomy and Synonymy of Several Species of Whale-lice (Cyamidae: Amphipoda). Journal of the Fisheries Research Board of Canada. 1955;(12): 121-33. 
3. Fransen CHJM, Smeenk C. Whale-lice (Amphipoda: Cyamidae) recorded from the Netherlands. Zoologische Mededelingen. 1992;(65): 393-405.

4. Rowntree VJ. Feeding, distribution, and reproductive behavior of cyamids (Crustacea: Amphipoda) living on humpback and right whales. Canadian Journal of Zoology. 1996;(74): 103-09.

5. Abollo E, López A, Gestal C, Benavente P, Pascual S. Macroparasites in cetaceans stranded on the northwestern Spanish Atlantic coast. Diseases of aquatic organisms. 1998;(32): 227-31.

6. Iwasaarai T, Serejo CS, Siciliano S, Ott PH, Freire AS, Elwen SH, Crespo EA, Colosio AC, Carvalho V, Rodriguezrey GT. The host-specific whale louse (Cyamus boopis) as a potential tool for interpreting humpback whale (Megaptera novaeangliae) migratory routes. Journal of Experimental Marine Biology Ecology. 2018;(505): 45-51.

7. Iwasaarai T, Freire AS, Colosio AC, Serejo CS. Ontogenetic development and redescription of the whale louse Cyamus boopis Lütken, 1870 (Crustacea: Amphipoda: Cyamidae), ectoparasite of humpback whale Megaptera novaeangliae (Mammalia: Cetacea: Balaenopteridae). Marine Biodiversity. 2017;(47): 1-11.

8. Leung YJC. An Illustrated Key To the Species of Whale-Lice (Amphipoda, Cyamidae), Ectoparasites of Cetacea, With a Guide To the Literature. 1967;(12): 279-91.

9. Margilis L, McDonald TE, Bousfield EL. The whale lice (Amphipoda: Cyamidae) of the northeastern Pacific Region. Amphipacifica: journal of systematic biology. 2000;(2): 63-117.

10. Leung YM. An Illustrated Key To the Species of Whale-Lice (Amphipoda, Cyamidae), Ectoparasites of Cetacea, With a Guide To the Literature. Crustaceana. 1967;(12): 279-91.

11. Lütken CF. Conspectus Cyamidarum borealium hujusque cognitarum. Crustacea amphipoda borealia et arctica. 1870;(1870): 279-80.

12. Sars GO. An account of the Crustacea of Norway, with short descriptions and figures of all the species: VI., Copepoda Cyclopoida1913.

13. Pfeiffer CJ, Whale Lice, in: W.F. Perrin, B. Würsig, J.G.M. Thewissen, editors, Encyclopedia of Marine Mammals (Second Edition), Academic Press, London, 2009, pp. 1220-23.

14. Kaliszewska ZA, Seger J, Rowntree VJ, Barco SG, Benegas R, Best PB, Brown MW, Brownell RL, Carribero A, Harcourt RG. Population histories of right whales (Cetacea: Eubalaena) inferred from mitochondrial sequence diversities and divergences of their whale lice (Amphipoda: Cyamus). Molecular Ecology. 2005;(14): 3439-56.

15. Lehnert K, Fonfara S, Wohlsein P, Siebert U. Whale lice (Isocyamus delphinii) on a harbour porpoise (Phocoena phocoena) from German waters. Veterinary Record. 2007;(161): 526.

16. Jackson JA, Steel D, Beerli P, Congdon BC, Olavarria C, Leslie MS, Pomilla C, Rosenbaum HC, Baker CS. Global diversity and oceanic divergence of humpback whales (Megaptera novaeangliae). Proceedings of The Royal Society B: Biological Sciences. 2014;(281): 20133222.

17. Guindon S, Dufayard JF, Lefort V, Anisimova M, Hordijk W, Gascuel O. New algorithms and methods to estimate maximum-likelihood phylogenies: assessing the performance of PhyML 3.0. Systematic biology. 2010;(59): 307-21. 
18. Zhang NQ. The first record of the whale louse in China. Journal of Liaoning Normal University (Natural Science edition). 1980;(2): 29-31.

19. Callahan CM. Molecular systematics and population genetics of whale lice (Amphipoda: Cyamidae) living on gray whale islands Dissertation. Humboldt State University, Arcata, USA. 2008; (54 pp).

20. Woolfit M. Effective population size and the rate and pattern of nucleotide substitution. Biology letters. 2009;(5): 417-20.

\section{Figures}
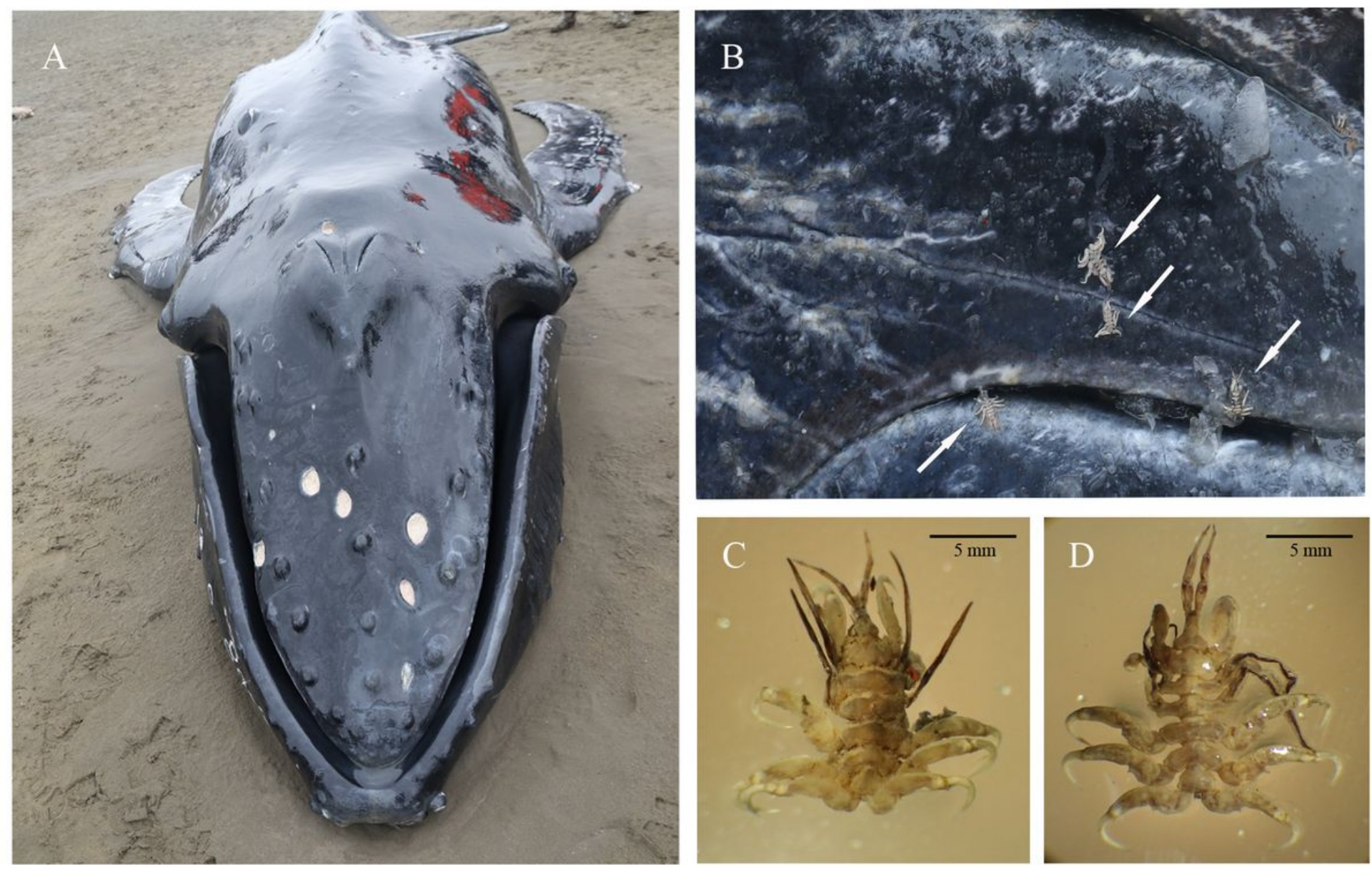

\section{Figure 1}

Whale lice collection from the carcass of a male humpback whale on the coast of the East China Sea. A) humpback whale; B) Whale lice on humpback whale, white arrow indicates the whale lice; C) Cyamus boopis Lütken, 1870. Female. Scale bar: 5 mm; D) Cyamus boopis Lütken, 1870. Male. Scale bar: $5 \mathrm{~mm}$ 


\section{Colored ranges}

Cyamus boopis

Cyamus erraticus

Cyamus gracilis

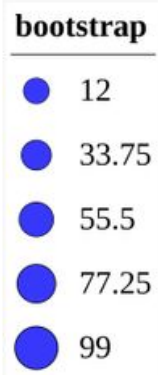

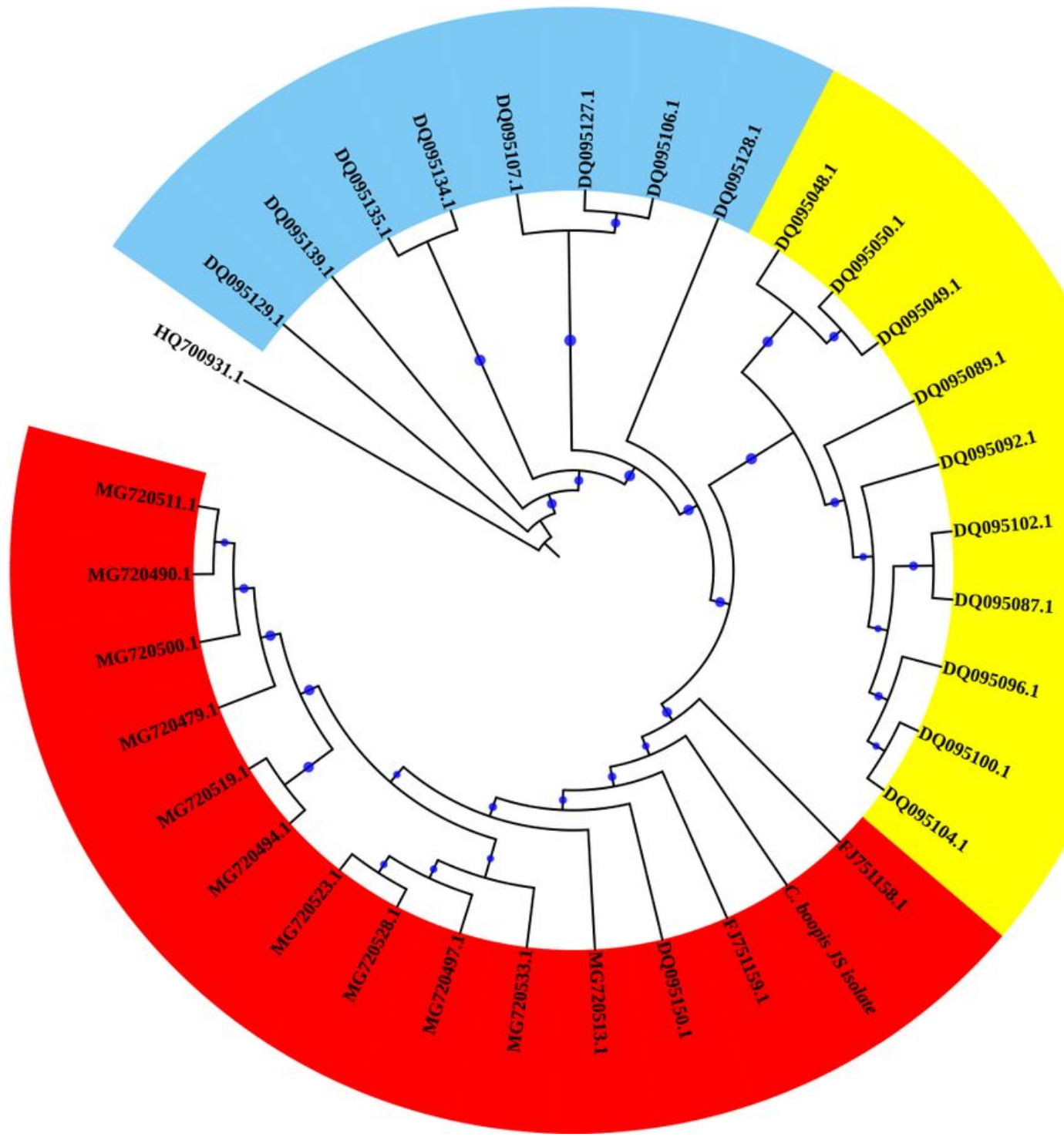

Figure 2

Phylogenetic tree of Cyamus boopis $\mathrm{COI}$ sequences constructed with maximum likelihood method using the online program PhyML 3.0. Node values represent the bootstrap confidence from 100 replicates. Red indicates Cyamus boopis. Yellow indicates Cyamus gracilis. Blue background indicates Cyamus erraticus 